TITLE:

\title{
Asymmetric Cycloetherifications by Bifunctional Aminothiourea Catalysts: The Importance of Hydrogen Bonding
}

\section{AUTHOR(S):}

Fukata, Yukihiro; Miyaji, Ryota; Okamura, Takaaki; Asano, Keisuke; Matsubara, Seijiro

\section{CITATION:}

Fukata, Yukihiro ...[et al]. Asymmetric Cycloetherifications by Bifunctional Aminothiourea Catalysts: The Importance of Hydrogen Bonding. Synthesis 2013, 45(12): 1627-1634

\section{ISSUE DATE:}

2013-06-05

URL:

http://hdl.handle.net/2433/189760

\section{RIGHT:}

(c) Georg Thieme Verlag Stuttgart · New York; この論文は出版社版であ りません。引用の際には出版社版をご確認ご利用ください。; This is not the published version. Please cite only the published version. 


\title{
Asymmetric Cycloetherifications by Bifunctional Aminothiourea Catalysts: The Importance of Hydrogen Bonding
}

\author{
Yukihiro Fukata, Ryota Miyaji, Takaaki Okamura, Keisuke Asano, ${ }^{*}$ and Seijiro Matsubara* \\ Department of Material Chemistry, Graduate School of Engineering, Kyoto University, Kyotodaigaku-Katsura, Nishikyo, Kyoto $615-$ \\ 8510, Japan
}

Fax: (+81) 75-383-2438

E-mail: keisuke.asano@t03kr913mk.mbox.media.kyoto-u.ac.jp; E-mail: matsubara.seijiro.2e@kyoto-u.ac.jp

Received: The date will be inserted once the manuscript is accepted.

\begin{abstract}
Chiral oxacyclic frameworks are prevalent in many natural products and bioactive compounds. In addition, a number of them are important synthetic intermediates. Thus, the synthesis of such structures is a significant goal in the field of organic chemistry. However, the development of catalytic asymmetric cycloetherification for the straightforward synthesis of these compounds remains a challenge. In this study, we propose the use of aminothiourea catalysis as an effective way to accomplish such a challenge. The asymmetric synthesis of chiral oxygen heterocycles, including tetrahydrofurans, tetrahydropyrans, and 1,3-dioxolanes, is demonstrated herein using intramolecular oxy-Michael addition mediated by bifunctional aminothiourea catalysts.
\end{abstract}

Key words: oxycyclization, cycloetherification, hydrogen bonding, bifunctional aminothiourea catalyst, oxy-Michael addition

Cyclization from unsaturated substrates that bear a pendant nucleophilic oxygen atom is a straightforward way to synthesize chiral oxacyclic compounds. However, asymmetric oxycyclization reactions are highly challenging because of the difficulty in installing a suitable chiral environment during the rapid intramolecular process. On the other hand, several asymmetric azacyclizations have successfully been developed, including enantioselective intramolecular aza-Michael additions using a prolinederived catalyst ${ }^{1}$ or a chiral phase-transfer-catalyst. ${ }^{2}$ The enantioselection of these azacyclizations was largely controlled by the effects of the substituents on the nucleophilic nitrogen atom through steric repulsion or $\pi$-interactions. Meanwhile, because such a substituent is lacking in the oxycyclization substrates, those strategies can only be applied to starting materials that bear an appropriate substituent in the vicinity of the alcohol., ${ }^{3,4}$ Therefore, a novel strategy is required to obtain an efficient asymmetric oxycyclization reaction. In this context, hydrogen bonding is an interaction with the potential to be able to control the behavior of a pendant $\mathrm{OH}$ group (Scheme 1). Thus, the use of organocatalysts that utilize hydrogen bonding ${ }^{5}$ is a promising approach to realizing enantioselective oxycyclization. Moreover, multipoint recognition by an asymmetric catalyst would be favorable for the achievement of effective transfer of the chiral information during the cyclization process (Scheme 1).

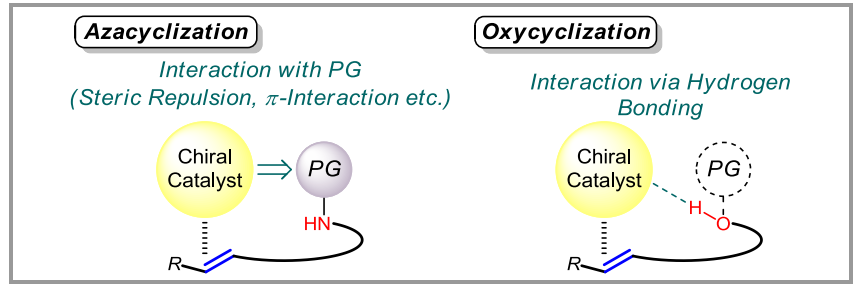

Scheme 1 Strategies for asymmetric aza- and oxycyclizations. (PG: protecting group)

Evidence for the validity of this concept can be found in some recent reports on catalytic asymmetric halolactonizations using bifunctional organocatalysts. These allow multipoint interactions in the reaction transition states, one of which is hydrogen bonding with the pendant carboxyl group. ${ }^{6}$ In addition, a number of other highly enantioselective oxycyclizations using organocatalysts have been developed, where hydrogen bonding is thought to have played a role in controlling the chirality. ${ }^{7-10}$

However, whereas an increasing number of methods for asymmetric cyclolactonizations have recently been reported ${ }^{6}$ examples of cycloetherifications are still limited. ${ }^{3,7,9,10}$ In particular, catalytic enantioselective cycloetherifications are extremely challenging because of the higher nucleophilicity of hydroxyl groups compared to carboxyl groups. In fact, several of the previously reported cycloetherifications demonstrated only moderate enantioselectivity, resulting from background racemic reactions that occurred, even at low temperatures. They therefore required a stoichiometric or extremely high loading of chiral mediators in order to achieve acceptable selectivity. ${ }^{11} \quad$ To overcome such drawbacks, we developed an intramolecular oxy-Michael addition reaction ${ }^{12}$ by employing bifunctional aminothiourea catalysts $^{13}$ that utilize hydrogen bonding at both catalytic sites. It was hypothesized that the mild character of hydrogen bonding would facilitate concerted catalysis through multipoint recognition, even with highly reactive substrates, for cycloetherification (Scheme 2). ${ }^{7 a, b}$ 


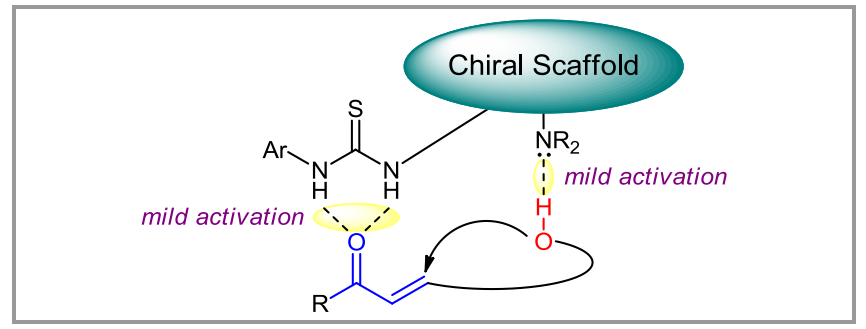

Scheme 2 Asymmetric cycloetherification via intramolecular oxyMichael addition reaction mediated by bifunctional organocatalyst.

Herein, we describe a highly enantioselective catalytic cycloetherification for the synthesis of 2-substituted tetrahydrofurans (Table 1) and tetrahydropyrans (Table 2). ${ }^{14}$ An intramolecular oxy-Michael addition reaction from $\varepsilon$ - or $\zeta$-hydroxy- $\alpha, \beta$-unsaturated ketones could be performed in a highly enantioselective fashion by using cinchona-alkaloid-thiourea-based bifunctional organocatalyst 3a (Figure 1). Screening of the catalysts shown in Figure 1 further demonstrated that $\mathbf{3 c}$ is an efficient catalyst for obtaining the opposite enantiomer ent-2a in excellent yield with high enantioselectivity (Table 1, entry 2). Moreover, the catalytic loading could be decreased to as low as $1 \mathrm{~mol} \%$ in the THF synthesis, while still giving excellent enantioselectivity (Table 1, entry 3 ). This catalytic process is a highly practical cycloetherification method that provides excellent enantioselectivities, even with low catalyst loadings at ambient temperature. Although the reactions were slower, a similar reaction condition also led to the highly enantioselective synthesis of 2-substituted tetrahydropyrans (Table 2).

Table 1. Asymmetric Synthesis of 2-Substituted Tetrahydrofurans via Cycloetherification Using Bifunctional Organocatalysts ${ }^{\mathrm{a}, \mathrm{b}}$

\begin{tabular}{l} 
COME, 25 ${ }^{\circ} \mathrm{C}, 24 \mathrm{~h}$ \\
\cline { 3 - 5 }
\end{tabular}

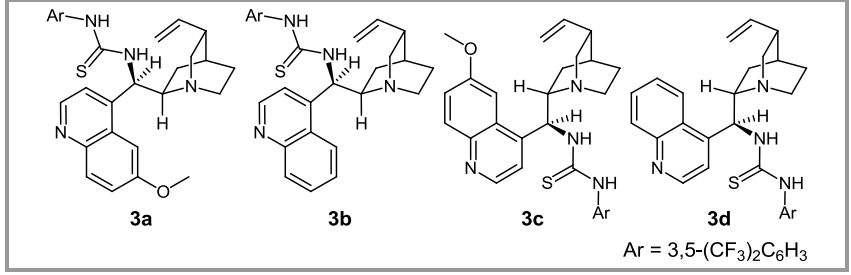

Figure 1 Cinchona-alkaloid-derived aminothiourea catalysts.

Table 2. Asymmetric Synthesis of 2-Substituted Tetrahydropyrans via Cycloetherification Using Bifunctional Organocatalysts ${ }^{\mathrm{a}, \mathrm{b}}$

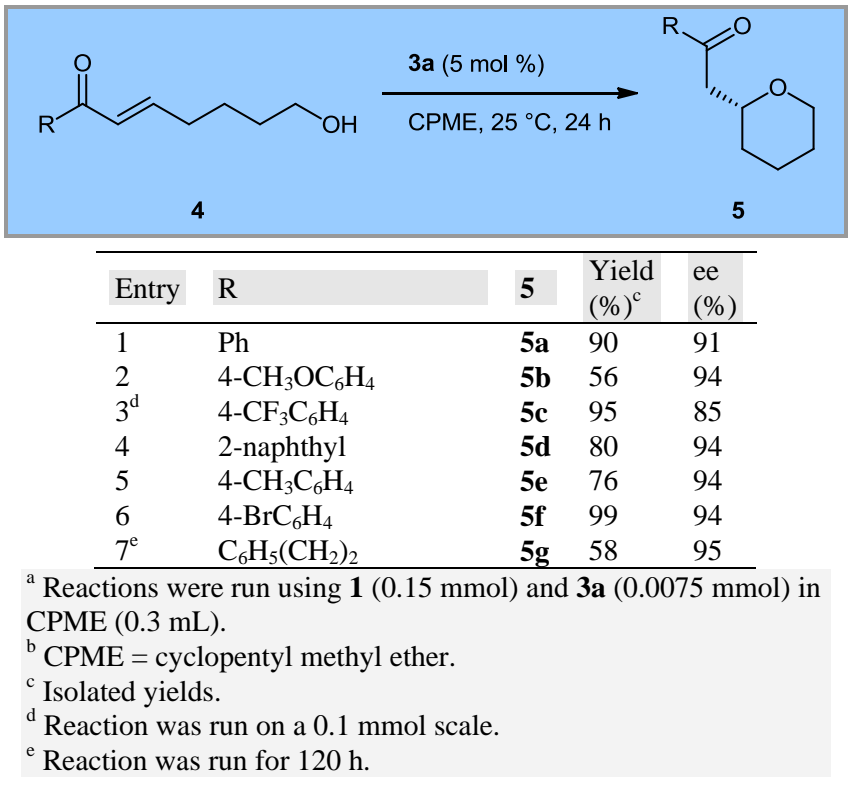

The obtained THF product $\mathbf{2 b}$ could be further transformed into the corresponding ester $\mathbf{6}$ by means of Baeyer-Villiger oxidation with $m$-CPBA in the presence of TFA in $92 \%$ yield without any loss of optical purity (Scheme 3). Subsequent reduction of 6 with lithium aluminum hydride afforded $(R)$-2(tetrahydrofuran-2-yl)ethanol (7), which is a valuable synthetic intermediate (Scheme 3$)^{15}$

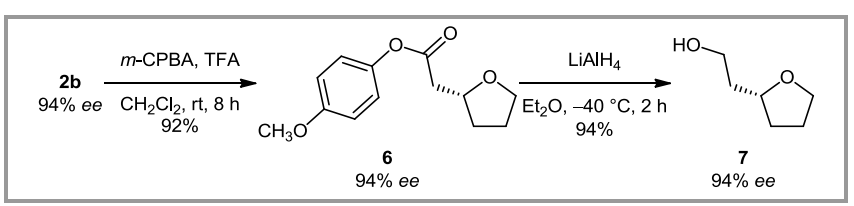

Scheme $\mathbf{3}$ Transformation of $\mathbf{2 b}$.

These results subsequently motivated us to exploit this efficient oxycyclization protocol for the development of a catalytic formal [3+2] cycloaddition reaction starting from $\gamma$-hydroxy- $\alpha, \beta$-unsaturated carbonyls ${ }^{16}$ with aldehydes or ketones (Scheme 4$)$. This method led to the successful divergent synthesis of chiral 1,3dioxolanes. $^{17}$ In this reaction, the hemiacetal intermediate generated in situ was the substrate for the cycloetherification mediated by chiral aminothiourea. ${ }^{18,19}$ 


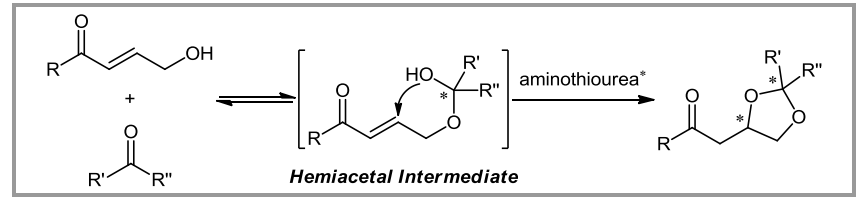

Scheme 4 Chiral 1,3-dioxolane synthesis via asymmetric cycloetherification using a bifunctional aminothiourea catalyst.

Employing the conditions described in Table 3, various 1,3-dioxolanes were stereoselectively obtained by the formal cycloaddition reaction using $\mathbf{3 a}$ as a catalyst. ${ }^{20}$ In addition, catalyst screening identified $\mathbf{3 c}$ as an efficient catalyst for obtaining the opposite enantiomer ent-10aa in good yield with high enantioselectivity (Table 3, entry 2 ).

Table 3. Asymmetric Synthesis of 1,3-Dioxolanes by organocatalytic formal $[3+2]$ cycloaddition $^{\text {a,b }}$

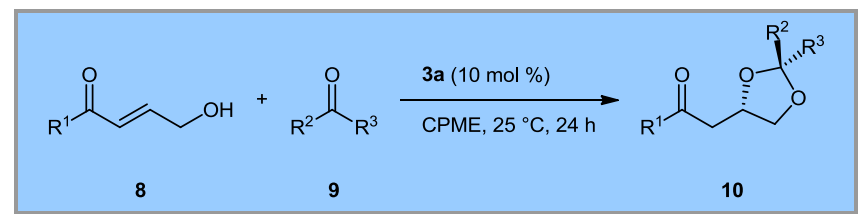

\begin{tabular}{llllll}
\hline Entry & $\mathrm{R}^{1}, \mathrm{R}^{2}, \mathrm{R}^{3}$ & $\mathbf{1 0}$ & $\begin{array}{l}\mathrm{Yield}^{\mathrm{c}} \\
(\%)^{\mathrm{c}}\end{array}$ & $\mathrm{dr}^{\mathrm{d}}$ & $\begin{array}{l}\mathrm{ee} \\
(\%)^{\mathrm{e}}\end{array}$ \\
\hline 1 & $\mathrm{Ph}, \mathrm{Cy}, \mathrm{H}$ & $\mathbf{1 0 a a}$ & 95 & $3.0: 1$ & 96 \\
$2^{\mathrm{f}}$ & $\mathrm{Ph}, \mathrm{Cy}, \mathrm{H}$ & ent-10aa & 91 & $4.0: 1$ & -93 \\
$3^{\mathrm{g}}$ & 4- $\mathrm{CH}_{3} \mathrm{OC}_{6} \mathrm{H}_{4}, \mathrm{Cy}, \mathrm{H}$ & $\mathbf{1 0 b a}$ & 93 & $3.4: 1$ & 96 \\
4 & 4- $\mathrm{CF}_{3} \mathrm{C}_{6} \mathrm{H}_{4}, \mathrm{Cy}, \mathrm{H}$ & $\mathbf{1 0 c a}$ & 83 & $2.5: 1$ & 95 \\
5 & 4- $\mathrm{BrC}_{6} \mathrm{H}_{4}, \mathrm{Cy}, \mathrm{H}$ & $\mathbf{1 0 d a}$ & 88 & $4.7: 1$ & 96 \\
6 & 2- $\mathrm{CH}_{3} \mathrm{C}_{6} \mathrm{H}_{4}, \mathrm{Cy}, \mathrm{H}$ & $\mathbf{1 0 e a}$ & 71 & $3.3: 1$ & 91 \\
7 & 1-naphthyl, Cy, H & $\mathbf{1 0 f a}$ & 82 & $2.9: 1$ & 90 \\
8 & 2-thienyl, Cy, H & $\mathbf{1 0 g a}$ & 84 & $3.3: 1$ & 98 \\
$9^{\mathrm{h}}$ & $\mathrm{C}_{6} \mathrm{H}_{5}\left(\mathrm{CH}_{2}\right)_{2}, \mathrm{Cy}, \mathrm{H}$ & $\mathbf{1 0 h a}$ & 82 & $3.3: 1$ & 96 \\
10 & $\mathrm{Ph}, \mathrm{Et}, \mathrm{H}$ & $\mathbf{1 0 a b}$ & 94 & $3.0: 1$ & 94 \\
11 & $\mathrm{Ph}, i-\mathrm{Pr}, \mathrm{H}$ & $\mathbf{1 0 a c}$ & 92 & $2.7: 1$ & 93 \\
$12^{\mathrm{i}}$ & $\mathrm{Ph}, t-\mathrm{Bu}, \mathrm{H}$ & $\mathbf{1 0 a d}$ & 84 & $2.6: 1$ & 94 \\
13 & $\mathrm{Ph}, \mathrm{CF} F_{3}, \mathrm{Ph}$ & $\mathbf{1 0 a e}$ & 99 & $1.2: 1$ & 70 \\
\hline${ }^{\mathrm{a}} \mathrm{Reaction}$
\end{tabular}

${ }^{a}$ Reactions were run using $8(0.25 \mathrm{mmol}), 9(0.3 \mathrm{mmol})$, and $\mathbf{3 a}$

$(0.025 \mathrm{mmol})$ in CPME $(0.5 \mathrm{~mL})$.

${ }^{\mathrm{b}} \mathrm{CPME}=$ cyclopentyl methyl ether.

${ }^{\mathrm{c}}$ Isolated yields.

${ }^{\mathrm{d}}$ Diastereomeric ratios were determined by ${ }^{1} \mathrm{H}$ NMR.

${ }^{\mathrm{e}}$ Values are for the major diastereomers of $\mathbf{1 0}$. See ref 20 for

minor diastereomers.

${ }^{\mathrm{f}}$ Reaction was run using $\mathbf{3 c}$ instead of $\mathbf{3 a}$.

${ }^{\mathrm{g}}$ Reaction was run for $48 \mathrm{~h}$.

${ }^{\mathrm{h}}$ Reaction was run for $96 \mathrm{~h}$.

${ }^{\mathrm{i}}$ Reaction was run for $120 \mathrm{~h}$.

The utility of the products as synthetic intermediates was demonstrated by performing the transformation of 10aa. Reduction with lithium aluminum hydride in the presence of lithium iodide afforded the corresponding alcohol $\mathbf{1 1}$ with high diastereoselectivity, and subsequent de-acetalization gave optically active triol 12 (Scheme 5). In addition, treatment of 10aa with allyltrimethylsilane in the presence of titanium tetrachloride led to allylative ring cleavage to provide $\mathbf{1 3}$ in a regio- and diastereoselective fashion while maintaining the optical purity (Scheme 6).

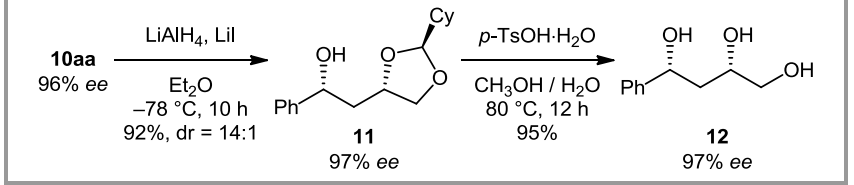

Scheme 5 Synthesis of chiral triol 12.

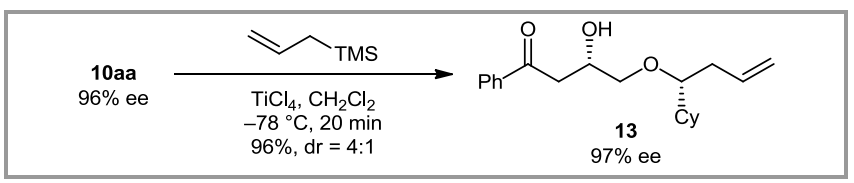

Scheme 6 Stereospecific ring cleavage of 10aa.

To gain further insight into the enantio-determining step, formal $[3+2]$ cycloaddition reactions were investigated using formaldehyde $(\mathbf{9 f})$ and acetone $(\mathbf{9 g})$ with 8a (Scheme 7). It was found that products 10af and 10ag were obtained enantioselectively, regardless of the achirality of the forming acetal carbon. These results strongly suggest that the intramolecular oxyMichael addition from the hemiacetal intermediates proceeded with high enantioselectivity according to our original hypothesis. This is also in agreement with the consistent absolute configuration (the same (S)-configuration) at the $\beta$-position of the carbonyl group in both diastereomers of 10da (Scheme 8).

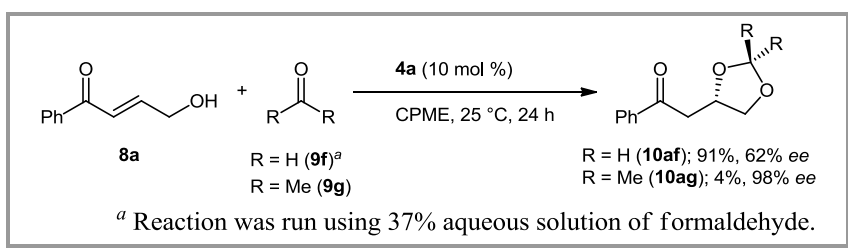

Scheme 7 Formal [3+2] cycloaddition with formaldehyde (9f) and acetone $(\mathbf{9 g})$.

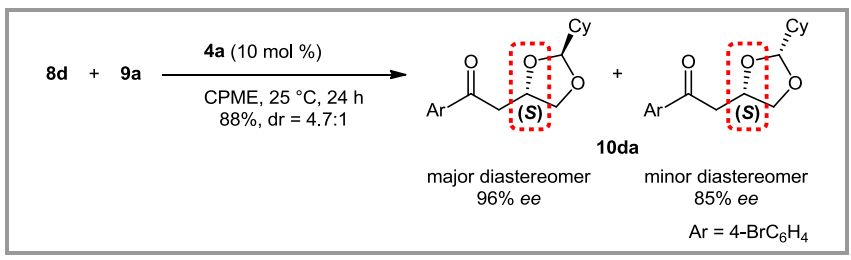

Scheme 8 The absolute configurations of $\mathbf{1 0 d a}$, as determined by $\mathrm{X}$-ray analysis for both diastereomers. ${ }^{21}$

Considering these stereochemical outcomes, although the diastereoselectivity was only moderate, these reactions can be recognized as a way to achieve highly enantioselective oxygen atom introduction at the $\beta$ position of the carbonyl group. This cyclization protocol was therefore applied to reactions using carboxylic acid derivatives as substrates. There have been very few demonstrations of asymmetric oxyMichael additions to high oxidation state substrates, such as $\alpha, \beta$-unsaturated carboxylic acid derivatives, ${ }^{22}$ despite their great synthetic importance. ${ }^{23}$

By employing studies involving the optimization of substrates and reaction conditions, 2,6- 
dimethylbenzenethiol ester 14 was identified as the best substrate, and pivalaldehyde (9d) proved to be a good counterpart. The reaction between these components, using $\mathbf{3 a}$ as a catalyst, gave a diastereomer mixture of the desired products (15 and $\mathbf{1 5}^{\prime}$ ) in high yield, with excellent enantioselectivity for both diastereomers (Scheme 9). ${ }^{24}$ Stereochemical analysis of the products revealed that these diastereomers had the same $(S)$-configuration at the $\beta$ position of the carbonyl group as was expected. ${ }^{25}$

The easily removable acetal functionality enables this oxy-Michael addition method to be useful as an enantioselective formal hydration. ${ }^{26}$ In order to demonstrate this, the obtained products were further extended to the asymmetric syntheses of some $\beta$ hydroxy carboxyl compounds (Scheme 10). Treatment of the diastereomer mixture of $\mathbf{1 5}$ and 15' with titanium tetrachloride led to the generation of free $\beta, \gamma$-dihydroxy compound $\mathbf{1 6}$ with high optical purity, while keeping the thioester group intact. Alternatively, treatment of the diastereomer mixture with $p$-toluenesulfonic acid in an aqueous medium gave $\beta$-hydroxy- $\gamma$-butyrolactone 17 , a versatile chiral synthetic intermediate, ${ }^{27}$ which could be transformed into $(L)$-carnitine $(\mathbf{1 8})$, an important bioactive agent, using a previously reported procedure. ${ }^{28}$

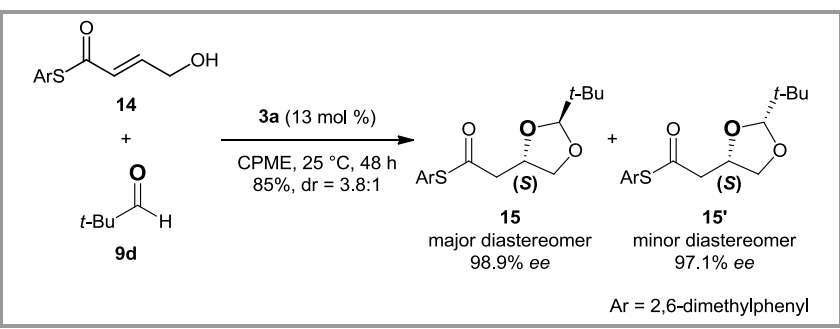

Scheme 9 Asymmetric oxy-Michael addition to $\gamma$-hydroxy- $\alpha, \beta$ unsaturated thioester 14.

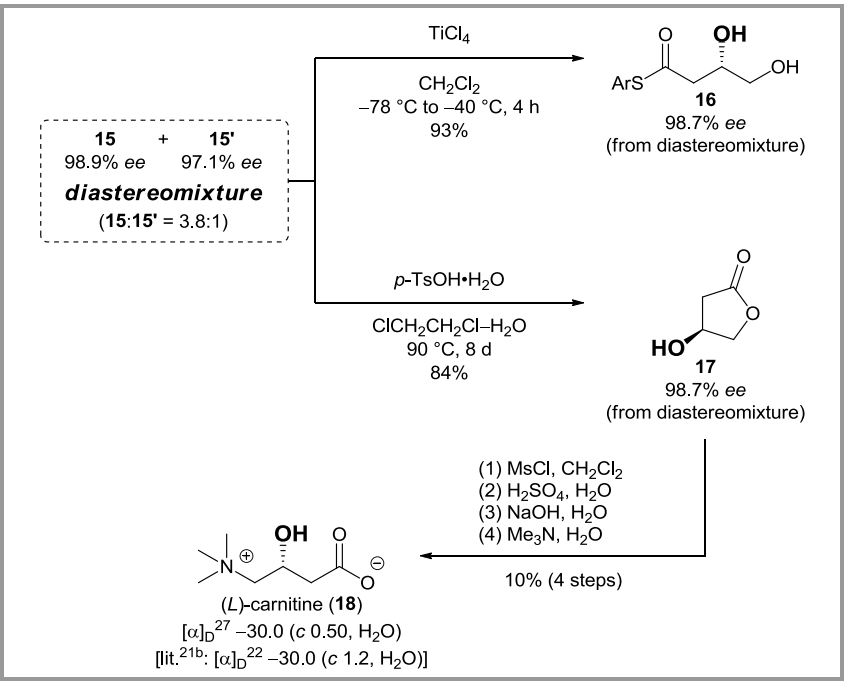

Scheme 10 Syntheses of chiral $\beta$-hydroxy carboxyl compounds.

Taking advantage of the thioester functionality, we also carried out functional group transformations of
15, and it was found that the chiral acetal moiety was unchanged after the transformations (Scheme 11). Reduction of $\mathbf{1 5}$ with lithium aluminium hydride afforded the corresponding primary alcohol 19 quantitatively, without any erosion of optical purity. In addition, Liebeskind-Srogl cross coupling enabled the replacement of the arylthio group of $\mathbf{1 5}$ to give ketone 10ad, ${ }^{29}$ indicating that these thioester products can be easily transformed into a wide variety of chiral compounds.

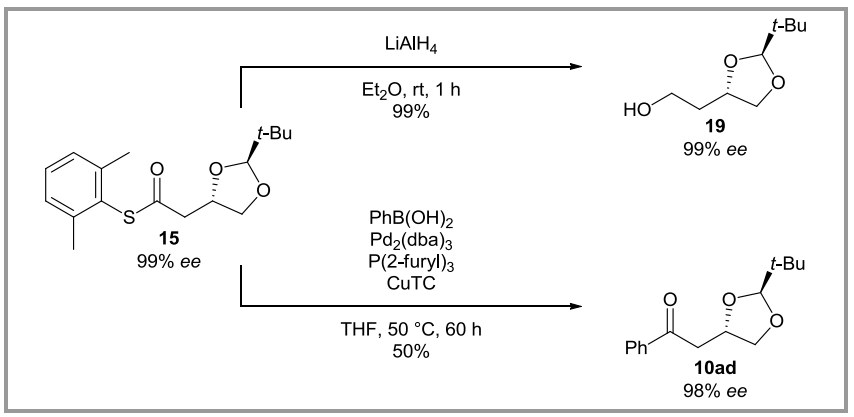

Scheme 11 Transformations of the thioester group of $\mathbf{1 5}$

In summary, we have demonstrated asymmetric intramolecular oxy-Michael addition reactions using cinchona-alkaloid-thiourea-based bifunctional organocatalysts. The developed methods afforded several important oxacyclic compounds, including tetrahydrofurans, tetrahydropyrans, and 1,3dioxolanes. A number of the resulting products were demonstrated to be useful synthetic intermediates that could be further transformed into valuable bioactive compounds. This study indicates that the approach based on the use of hydrogen bonding is an effective way to achieve enantioselective cycloetherification. Further studies on the application of this methodology to the synthesis of other chiral oxygen heterocycles are currently underway in our laboratory and will be reported in due course.

${ }^{1} \mathrm{H}$ and ${ }^{13} \mathrm{C}$ Nuclear magnetic resonance spectra were taken on a Varian UNITY INOVA $500\left({ }^{1} \mathrm{H}, 500 \mathrm{MHz}\right.$; ${ }^{13} \mathrm{C}, 125.7 \mathrm{MHz}$ ) spectrometer using tetramethylsilane as an internal standard for ${ }^{1} \mathrm{H}$ NMR $(\delta=0 \mathrm{ppm})$ and $\mathrm{CDCl}_{3}$ as an internal standard for ${ }^{13} \mathrm{C}$ NMR $(\delta=77.0$ ppm). When a ${ }^{13} \mathrm{C}$ NMR spectrum was measured using $\mathrm{C}_{6} \mathrm{D}_{6}$ as a solvent, $\mathrm{C}_{6} \mathrm{D}_{6}$ was used as an internal standard $(\delta=128.06 \mathrm{ppm}) .{ }^{1} \mathrm{H}$ NMR data are reported as follows: chemical shift, multiplicity ( $\mathrm{s}=$ singlet, $\mathrm{d}=$ doublet, $\mathrm{t}=$ triplet, $\mathrm{q}=$ quartet, quint $=$ quintet, sext $=$ sextet, sept $=$ septet, br $=$ broad, $\mathrm{m}=$ multiplet), coupling constants $(\mathrm{Hz})$, integration. ${ }^{19} \mathrm{~F}$ NMR spectra were measured on a Varian Mercury 200 $\left({ }^{19} \mathrm{~F}, 188 \mathrm{MHz}\right)$ spectrometer with hexafluorobenzene as an internal standard ( $\delta=0 \mathrm{ppm})$. GC-MS analyses and High-resolution mass spectra were obtained with 
a JEOL JMS-700 spectrometer by electron ionization at $70 \mathrm{eV}$. High performance liquid chromatography (HPLC) was performed with a SHIMADZU Prominence. Infrared (IR) spectra were determined on a SHIMADZU IR Affinity-1 spectrometer. Melting points were determined using a YANAKO MP-500D. Optical rotations were measured on a HORIBA SEPA-200. X-ray data were taken on a Bruker Smart APEX X-Ray diffractometer equipped with a large area CCD detector. The structures were solved with the program system SHELXS-97 and refined with SHELXL-97 package from Bruker. TLC analyses were performed by means of Merck Kieselgel $60 \mathrm{~F}_{254}(0.25 \mathrm{~mm})$ Plates. Visualization was accomplished with UV light (254 nm) and/or such as an aqueous alkaline $\mathrm{KMnO}_{4}$ solution followed by heating.

Flash column chromatography was carried out using Kanto Chemical silica gel (spherical, 40-50 $\mu \mathrm{m}$ ). Unless otherwise noted, commercially available reagents were used without purification.

\section{General procedure for preparation of bifunctional aminothiourea catalysts 3}

Bifunctional organocatalysts $\mathbf{3}$ were prepared by the literature procedure. ${ }^{13 \mathrm{c}}$ A cinchona alkaloid $(5 \mathrm{mmol})$ and triphenylphosphine (1.6 g, $6 \mathrm{mmol})$ were dissolved in THF $(25 \mathrm{~mL})$, and the solution was cooled to $0{ }^{\circ} \mathrm{C}$. Diethyl azodicarboxylate $(1.0 \mathrm{~g}, 6$ mmol) was subsequently added. To the resulting solution was added dropwise the solution of diphenyl phosphoryl azide $(1.3 \mathrm{~mL}, 6 \mathrm{mmol})$ in THF $(10 \mathrm{~mL})$ at $0{ }^{\circ} \mathrm{C}$. The mixture was allowed to warm to ambient temperature. After being stirred for $24 \mathrm{~h}$, it was heated to $50{ }^{\circ} \mathrm{C}$ and stirred for $10 \mathrm{~h}$. Triphenylphosphine $(1.7 \mathrm{~g}, 6.5 \mathrm{mmol})$ was added again, and the mixture was stirred at $50{ }^{\circ} \mathrm{C}$ for additional $15 \mathrm{~h}$. After the solution was cooled to ambient temperature, $\mathrm{H}_{2} \mathrm{O}(0.5 \mathrm{~mL})$ was added, and the solution was stirred for $24 \mathrm{~h}$. The solvents were removed in vacuo, and the residue was dissolved in $\mathrm{CH}_{2} \mathrm{Cl}_{2} / 10 \%$ aqueous hydrochloric acid $(25 \mathrm{~mL} / 25$ $\mathrm{mL})$. The aqueous phase was separated and washed with $\mathrm{CH}_{2} \mathrm{Cl}_{2}(25 \mathrm{~mL} \times 4)$. It was subsequently made alkaline with aqueous ammonia, and the aqueous phase was extracted with $\mathrm{CH}_{2} \mathrm{Cl}_{2}(25 \mathrm{~mL} \times 4)$. The combined organic layers were dried over $\mathrm{Na}_{2} \mathrm{SO}_{4}$, and concentrated in vacuo. Purification by flash silica gel column chromatography using EtOAc/ $\mathrm{CH}_{3} \mathrm{OH}(\mathrm{v} / \mathrm{v}=$ 9/1) then $\mathrm{CHCl}_{3} / \mathrm{CH}_{3} \mathrm{OH}(\mathrm{v} / \mathrm{v}=8 / 2)$ as an eluent gave the corresponding 9-amino(9-deoxy)cinchona alkaloids. Next, to the solution of the obtained 9amino(9-deoxy)cinchona alkaloid in THF $(6 \mathrm{~mL})$ was slowly added a solution of 3,5bis(trifluoromethyl)phenyl isothiocyanate (1 equiv) in THF (4 mL) at ambient temperature. The mixture was stirred overnight, and the solvents were removed in vacuo. Purification by flash silica gel column chromatography using EtOAc/ $\mathrm{CH}_{3} \mathrm{OH}(\mathrm{v} / \mathrm{v}=95 / 5-$
97.5/2.5) or EtOAc as an eluent gave the corresponding bifunctional organocatalyst $\mathbf{3}$.

3a. White solid; $41 \%$ yield (1.2 g) (for 2 steps from quinidine $) . \quad[\alpha]_{\mathrm{D}}{ }^{23}+122.6\left(c 1.33, \mathrm{CH}_{2} \mathrm{Cl}_{2}\right) .{ }^{1} \mathrm{H} \mathrm{NMR}$ $\left(\mathrm{CDCl}_{3}\right) \delta 8.65($ br s, $1 \mathrm{H}), 8.02(\mathrm{~d}, J=9.0 \mathrm{~Hz}, 1 \mathrm{H})$, $7.86(\mathrm{~s}, 2 \mathrm{H}), 7.67$ (s, 1H), 7.59 (br s, 1H), 7.40 (d, J = $9.0 \mathrm{~Hz}, 1 \mathrm{H}), 7.23$ (br s, 1H), 5.86 (br s, 2H), 5.19 (br s, $1 \mathrm{H}), 5.15(\mathrm{~d}, J=9.5 \mathrm{~Hz}, 1 \mathrm{H}), 3.97(\mathrm{~s}, 3 \mathrm{H}), 3.22$ (br s, $1 \mathrm{H}), 3.10$ (br s, 1H), 3.03 (m, 2H), 2.94 (m, 1H), 2.38 $(\mathrm{m}, 1 \mathrm{H}), 1.70(\mathrm{~s}, 1 \mathrm{H}), 1.61(\mathrm{~m}, 2 \mathrm{H}), 1.27$ (br s, 1H), $1.02(\mathrm{~m}, 1 \mathrm{H}) .{ }^{13} \mathrm{C}$ NMR $\left(\mathrm{CDCl}_{3}\right) \delta 181.0,158.1$, $147.3,144.7,144.5,140.1,139.6,132.5$ (q, $J=33.6$ $\mathrm{Hz}), 131.6,128.0,123.5,122.9(\mathrm{q}, J=273.0 \mathrm{~Hz})$, 122.3, 118.7, 115.3, 101.7, 61.4, 55.6, 48.5, 47.1, 38.7, 27.1, 26.1, 25.0. Mp. 125.0-125.2 ${ }^{\circ} \mathrm{C}$. IR (KBr): $3221,2944,2361,1735,1623,1511,1475,1384$, 1278, 1177, 1134, 1034, 959, 916, 884, 850, 826, 682 $\mathrm{cm}^{-1}$. HRMS Calcd for $\mathrm{C}_{29} \mathrm{H}_{29} \mathrm{~F}_{6} \mathrm{~N}_{4} \mathrm{OS}:[\mathrm{M}+\mathrm{H}]^{+}$, 595.1966. Found: $m / z$ 595.1961.

3b. White solid; $36 \%$ yield $(1.0 \mathrm{~g}$ ) (for 2 steps from cinchonine $) .[\alpha]_{\mathrm{D}}{ }^{23}+163.3\left(c 1.23, \mathrm{CH}_{2} \mathrm{Cl}_{2}\right) .{ }^{1} \mathrm{H} \mathrm{NMR}$ $\left(\mathrm{CDCl}_{3}\right) \delta 8.83$ (br s, $\left.1 \mathrm{H}\right), 8.28$ (br s, $\left.1 \mathrm{H}\right), 8.15(\mathrm{~d}, J=$ $8.5 \mathrm{~Hz}, 1 \mathrm{H}), 7.85$ (br s, 2H), 7.56 (dd, $J=7.5,7.5 \mathrm{~Hz}$, 1H), 7.68 (s, 1H), 7.64 (dd, $J=7.5,7.5 \mathrm{~Hz}, 1 \mathrm{H}), 7.29$ (br s, 1H), 5.81 (br s, 2H), 5.14 (m, 2H), 3.21 (br s, $1 \mathrm{H}), 3.00$ (m, 3H), 2.92 (br s, 1H), $2.36(\mathrm{~m}, 1 \mathrm{H}), 1.66$ (s, 1H), 1.59 (m, 2H), 1.22 (br s, 1H), $0.95(\mathrm{~m}, 1 \mathrm{H})$. ${ }^{13} \mathrm{C} \mathrm{NMR}\left(\mathrm{CDCl}_{3}\right) \delta 181.3,150.0,148.6,145.8,140.2$, $139.3,132.5(\mathrm{q}, J=33.6 \mathrm{~Hz}), 130.5,129.5,127.1$, $126.7,123.4,122.9(\mathrm{q}, J=273.1 \mathrm{~Hz}), 122.8,119.0$, $118.7,115.5,61.8,55.7,48.5,47.0,38.9,27.3,26.0$, 24.9. Mp. 189.9-190.3 ${ }^{\circ} \mathrm{C}$. IR (KBr): 3428, 3246, 2944, 2360, 1622, 1588, 1512, 1474, 1386, 1281, $1183,1126,960,882,848,752,682 \mathrm{~cm}^{-1}$. HRMS Calcd for $\mathrm{C}_{28} \mathrm{H}_{27} \mathrm{~F}_{6} \mathrm{~N}_{4} \mathrm{~S}$ : $[\mathrm{M}+\mathrm{H}]^{+}$, 565.1861. Found: $\mathrm{m} / \mathrm{z} 565.1855$.

3c. White solid; $27 \%$ yield $(0.80 \mathrm{~g}$ ) (for 2 steps from quinine). $\quad[\alpha]_{\mathrm{D}}{ }^{23}-99.0\left(c 1.24, \mathrm{CH}_{2} \mathrm{Cl}_{2}\right) .{ }^{1} \mathrm{H}$ NMR $\left(\mathrm{CDCl}_{3}\right) \delta 8.60($ br s, $1 \mathrm{H}), 8.00(\mathrm{~d}, J=8.5 \mathrm{~Hz}, 1 \mathrm{H})$, 7.82 (br s, 2H), 7.68 (s, 1H), 7.62 (br s, 1H), 7.39 (d, $J$ $=8.5 \mathrm{~Hz}, 1 \mathrm{H}), 7.18($ br s, $1 \mathrm{H}), 5.84(\mathrm{br} \mathrm{s}, 1 \mathrm{H}), 5.70(\mathrm{~m}$, 1H), $5.01(\mathrm{~m}, 2 \mathrm{H}), 3.96$ (s, 3H), 3.37 (br s, 1H), 3.30 (br s, 1H), 3.18 (m, 1H), 2.79 (br s, 2H), 2.35 (br s, 1H), 1.72 (s, 1H), $1.68(\mathrm{~m}, 2 \mathrm{H}), 1.41(\mathrm{~m}, 1 \mathrm{H}), 0.92(\mathrm{br}$ $\mathrm{s}, 1 \mathrm{H}) .{ }^{13} \mathrm{C} \mathrm{NMR}\left(\mathrm{CDCl}_{3}\right) \delta 181.0,158.2,147.4$, $144.8,144.0,140.6,140.0,132.6(\mathrm{q}, J=33.6 \mathrm{~Hz})$, $131.8,127.9,123.6,122.9$ (q, $J=273.0 \mathrm{~Hz}$ ), 122.0, 118.8, 115.1, 102.1, 61.2, 55.7, 54.9, 41.3, 39.0, 27.5, 27.1, 25.7. Mp. 121.0-121.5 ${ }^{\circ} \mathrm{C}$. IR (neat): 3220 , 2946, 2360, 1623, 1510, 1475, 1384, 1279, 1180, 1134, 1032, 959, 917, 885, 850, $683 \mathrm{~cm}^{-1}$. HRMS Calcd for $\mathrm{C}_{29} \mathrm{H}_{29} \mathrm{~F}_{6} \mathrm{~N}_{4} \mathrm{OS}$ : $[\mathrm{M}+\mathrm{H}]^{+}$, 595.1966. Found: $\mathrm{m} / \mathrm{z}$ 595.1961. 
3d. White solid; $44 \%$ yield (1.2 g) (for 2steps from cinchonidine). $[\alpha]_{\mathrm{D}}^{23}-101.0\left(c 1.24, \mathrm{CH}_{2} \mathrm{Cl}_{2}\right) .{ }^{1} \mathrm{H}$ $\operatorname{NMR}\left(\mathrm{CDCl}_{3}\right) \delta 8.80($ br s, $1 \mathrm{H}), 8.35($ br s, $1 \mathrm{H}), 8.14$ $(\mathrm{d}, J=8.5 \mathrm{~Hz}, 1 \mathrm{H}), 7.80(\mathrm{~s}, 2 \mathrm{H}), 7.74(\mathrm{dd}, J=8.0,7.5$ $\mathrm{Hz}, 1 \mathrm{H}), 7.69$ (s, 1H), 7.63 (dd, $J=8.0,7.5 \mathrm{~Hz}, 1 \mathrm{H})$, 7.27 (br s, 1H), 5.78 (br s, 1H), $5.67(\mathrm{~m}, 1 \mathrm{H}), 4.98(\mathrm{~m}$, $2 \mathrm{H}), 3.26(\mathrm{~m}, 1 \mathrm{H}), 3.20(\mathrm{br} \mathrm{s}, 1 \mathrm{H}), 3.17(\mathrm{dd}, J=13.5$, $10.5 \mathrm{~Hz}, 1 \mathrm{H}), 2.78(\mathrm{~m}, 2 \mathrm{H}), 2.33(\mathrm{br} \mathrm{s}, 1 \mathrm{H}), 1.70(\mathrm{~m}$, $2 \mathrm{H}), 1.63(\mathrm{~m}, 1 \mathrm{H}), 1.33(\mathrm{~m}, 1 \mathrm{H}), 0.93(\mathrm{br} \mathrm{s}, 1 \mathrm{H}),{ }^{13} \mathrm{C}$ NMR $\left(\mathrm{CDCl}_{3}\right) \delta 180.9,149.9,148.5,145.9,140.7$, $139.9,132.6(\mathrm{q}, J=33.6 \mathrm{~Hz}), 130.4,129.5,127.0$, 123.6, $122.9(\mathrm{q}, J=273.0 \mathrm{~Hz}), 119.1,118.9,115.0$, $61.5,56.5,54.9,41.1,39.2,27.5,27.1,25.7$. Мp. $122.8-123.1{ }^{\circ} \mathrm{C}$. IR (neat): $3240,3081,2946,2366$, 1510, 1473, 1384, 1281, 1181, 1135, 990, 958, 884, $849,755,683 \mathrm{~cm}^{-1}$. HRMS Calcd for $\mathrm{C}_{28} \mathrm{H}_{27} \mathrm{~F}_{6} \mathrm{~N}_{4} \mathrm{~S}$ : $[\mathrm{M}+\mathrm{H}]^{+}$, 565.1861. Found: $m / z$ 565.1855.

\section{General procedure for asymmetric synthesis of 2- substituted tetrahydrofurans 2}

In a 5 -mL vial, we sequentially added $\varepsilon$-hydroxy- $\alpha, \beta$ unsaturated ketone $1(0.25 \mathrm{mmol})$, cyclopentyl methyl ether (CPME, $0.5 \mathrm{~mL}$ ), and quinidine-derived bifunctional catalyst 3a $(0.0075 \mathrm{mmol})$. The mixture was stirred in an oil bath maintained at $25{ }^{\circ} \mathrm{C}$ for $24 \mathrm{~h}$. The reaction mixture was subsequently diluted with hexane/EtOAc $(\mathrm{v} / \mathrm{v}=1 / 1)$, passed through a short silica gel pad to remove $\mathbf{3 a}$, and concentrated in vacuo. Purification of the reaction mixture by flash silica gel column chromatography using hexane/EtOAc $(\mathrm{v} / \mathrm{v}=$ $3 / 1)$ as an eluent afforded the corresponding 2substituted tetrahydrofuran 2 .

\section{General procedure for asymmetric synthesis of 2- substituted tetrahydropyrans 5}

In a 5 -mL vial, we sequentially added $\zeta$-hydroxy- $\alpha, \beta$ unsaturated ketone $4(0.15 \mathrm{mmol})$, cyclopentyl methyl ether (CPME, $0.3 \mathrm{~mL}$ ), and quinidine-derived bifunctional catalyst 3a $(0.0075 \mathrm{mmol})$. The mixture was stirred in an oil bath maintained at $25{ }^{\circ} \mathrm{C}$ for $24 \mathrm{~h}$. The reaction mixture was subsequently diluted with hexane/EtOAc $(\mathrm{v} / \mathrm{v}=1 / 1)$, passed through a short silica gel pad to remove $\mathbf{3 a}$, and concentrated in vacuo. Purification of the reaction mixture by flash silica gel column chromatography using hexane/EtOAc $(\mathrm{v} / \mathrm{v}=$ $3 / 1$ ) as an eluent afforded the corresponding tetrahydropyran $\mathbf{5}$.

\section{1-Phenyl-2-(tetrahydro-2H-pyran-2-yl)ethanone} (5a).

Yield: $90 \%(27.1 \mathrm{mg}), 91 \% e e$, colorless oil. $[\alpha]_{\mathrm{D}}{ }^{26}$ $+16.8\left(\right.$ c $\left.2.53, \mathrm{CH}_{2} \mathrm{Cl}_{2}\right) .{ }^{1} \mathrm{H}$ NMR $\left(\mathrm{CDCl}_{3}\right) \delta 7.97(\mathrm{~m}$, $2 \mathrm{H}), 7.56(\mathrm{~m}, 1 \mathrm{H}), 7.46(\mathrm{~m}, 2 \mathrm{H}), 3.96(\mathrm{~m}, 2 \mathrm{H}), 3.48$ (m, 1H), $3.29(\mathrm{dd}, J=16.0,6.5 \mathrm{~Hz}, 1 \mathrm{H}), 2.92(\mathrm{dd}, J=$ 16.0, $5.5 \mathrm{~Hz}, 1 \mathrm{H}), 1.84(\mathrm{~m}, 1 \mathrm{H}), 1.75(\mathrm{~m}, 1 \mathrm{H}), 1.57$ $(\mathrm{m}, 2 \mathrm{H}), 1.52(\mathrm{~m}, 1 \mathrm{H}), 1.36(\mathrm{~m}, 1 \mathrm{H}),{ }^{13} \mathrm{C} \mathrm{NMR}$ $\left(\mathrm{CDCl}_{3}\right) \delta 198.4,137.4,133.0,128.5,128.3,74.4$,
68.7, 45.4, 32.0, 25.9, 23.4. TLC: $\mathrm{R}_{\mathrm{f}} 0.45$ (hexane/EtOAc = 3:1). IR (neat): 3060, 2936, 2849, $1686,1597,1581,1449,1379,1357,1325,1292$, 1273, 1208, 1194, 1175, 1088, 1045, 1003, 971, 904, $810,777,751,692,661,471 \mathrm{~cm}^{-1}$. HRMS Calcd for $\mathrm{C}_{13} \mathrm{H}_{17} \mathrm{O}_{2}:[\mathrm{M}+\mathrm{H}]^{+}, 205.1229$. Found: $m / z$ 205.1227. HPLC (Daicel Chiralcel OD-H, hexane $/ i-\mathrm{PrOH}=99 / 1$, flow rate $\left.=2.0 \mathrm{~mL} / \mathrm{min}, \lambda=254 \mathrm{~nm}, 40{ }^{\circ} \mathrm{C}\right): t_{\text {minor }}=$ $6.1 \mathrm{~min}, t_{\text {major }}=8.0 \mathrm{~min}$.

\section{1-(4-Methoxyphenyl)-2-(tetrahydro-2H-pyran-2- yl)ethanone (5b).}

Yield: $56 \%(19.7 \mathrm{mg}), 94 \%$ ee, colorless oil. $[\alpha]_{\mathrm{D}}{ }^{25}$ $+20.8\left(c\right.$ 1.97, $\left.\mathrm{CH}_{2} \mathrm{Cl}_{2}\right)$. ${ }^{1} \mathrm{H}$ NMR $\left(\mathrm{CDCl}_{3}\right) \delta 7.95(\mathrm{~m}$, 2H), $6.91(\mathrm{~m}, 2 \mathrm{H}), 3.95(\mathrm{~m}, 1 \mathrm{H}), 3.93(\mathrm{~m}, 1 \mathrm{H}), 3.86(\mathrm{~s}$, $3 \mathrm{H}), 3.47(\mathrm{~m}, 1 \mathrm{H}), 3.23(\mathrm{dd}, J=16.0,7.0 \mathrm{~Hz}, 1 \mathrm{H})$, $2.86(\mathrm{dd}, J=16.0,6.0 \mathrm{~Hz}, 1 \mathrm{H}), 1.83(\mathrm{~m}, 1 \mathrm{H}), 1.73(\mathrm{~m}$, $1 \mathrm{H}), 1.59-1.49(\mathrm{~m}, 3 \mathrm{H}), 1.34(\mathrm{~m}, 1 \mathrm{H}) .{ }^{13} \mathrm{C}$ NMR $\left(\mathrm{CDCl}_{3}\right) \delta 196.9,163.4,130.5,130.1,113.6,74.4$, 68.6, 55.4, 45.0, 32.0, 25.8, 23.3. TLC: $\mathrm{R}_{\mathrm{f}} 0.29$ (hexane/EtOAc = 3:1). IR (neat): 2934, 2844, 1672, $1600,1577,1510,1309,1261,1170,1087,1045$, 1031, 843, $450 \mathrm{~cm}^{-1}$. HRMS Calcd for $\mathrm{C}_{14} \mathrm{H}_{19} \mathrm{O}_{3}$ : $[\mathrm{M}+\mathrm{H}]^{+}$, 235.1329. Found: $\mathrm{m} / \mathrm{z}$ 235.1377. HPLC (Daicel Chiralpak AD-H, hexane $/ i-\mathrm{PrOH}=98 / 2$, flow rate $=0.5 \mathrm{~mL} / \mathrm{min}, \lambda=254 \mathrm{~nm}, 40{ }^{\circ} \mathrm{C}$ ): $t_{\text {minor }}=34.6$ $\min , t_{\text {major }}=44.6 \mathrm{~min}$.

\section{1-(4-Trifluoromethylphenyl)-2-(tetrahydro-2H- pyran-2-yl)ethanone (5c).}

Reaction wasrun on 0.1 mmolscale.

Yield: $95 \%(25.9 \mathrm{mg}), 85 \% e e$, white solid. $[\alpha]_{\mathrm{D}}^{25}$ $+3.86\left(\right.$ c $\left.2.59, \mathrm{CH}_{2} \mathrm{Cl}_{2}\right) .{ }^{1} \mathrm{H}$ NMR $\left(\mathrm{CDCl}_{3}\right) \delta 8.06(\mathrm{~m}$, $2 \mathrm{H}), 7.72(\mathrm{~m}, 2 \mathrm{H}), 3.95(\mathrm{~m}, 1 \mathrm{H}), 3.93(\mathrm{~m}, 1 \mathrm{H}), 3.50$ (m, 1H), 3.30 (dd, $J=16.0,7.0 \mathrm{~Hz}, 1 \mathrm{H}), 2.90$ (dd, $J=$ $16.0,5.0 \mathrm{~Hz}, 1 \mathrm{H}), 1.85(\mathrm{~m}, 1 \mathrm{H}), 1.73(\mathrm{~m}, 1 \mathrm{H}), 1.59$ $(\mathrm{m}, 1 \mathrm{H}), 1.55(\mathrm{~m}, 1 \mathrm{H}), 1.52(\mathrm{~m}, 1 \mathrm{H}), 1.39(\mathrm{~m}, 1 \mathrm{H})$. ${ }^{13} \mathrm{C} \mathrm{NMR}\left(\mathrm{CDCl}_{3}\right) \delta 197.6,139.9,134.2(\mathrm{q}, J=32.7$ $\mathrm{Hz}), 128.6,125.6(\mathrm{q}, J=3.9), 123.5(\mathrm{q}, J=272.6 \mathrm{~Hz})$, 74.2, 68.6, 45.6, 31.9, 25.7, 23.3. ${ }^{19} \mathrm{~F} \mathrm{NMR}\left(\mathrm{CDCl}_{3}\right) \delta$ 98.7. Mp. $\quad 51.5-52.5{ }^{\circ} \mathrm{C}$. TLC: $\mathrm{R}_{\mathrm{f}} \quad 0.49$ (hexane/EtOAc = 3:1). IR (KBr): 2946, 2936, 2925 , $2857,1681,1412,1334,1323,1213,1170,1158,1134$, $1124,1113,1107,1084,1070,1006,848,829 \mathrm{~cm}^{-1}$. HRMS Calcd for $\mathrm{C}_{14} \mathrm{H}_{16} \mathrm{~F}_{3} \mathrm{O}_{2}:[\mathrm{M}+\mathrm{H}]^{+}, 273.1097$. Found: $m / z$ 273.1106. HPLC (Daicel Chiralpak AD-H, hexane $/ i-\mathrm{PrOH}=98 / 2$, flow rate $=0.5 \mathrm{~mL} / \mathrm{min}, \lambda=$ $254 \mathrm{~nm}, 40{ }^{\circ} \mathrm{C}$ ): $t_{\text {minor }}=15.8 \mathrm{~min}, t_{\text {major }}=18.9 \mathrm{~min}$.

\section{1-(Naphthalen-2-yl)-2-(tetrahydro-2H-pyran-2- yl)ethanone (5d).}

Yield: $80 \%(30.5 \mathrm{mg}), 94 \% e e$, colorless oil. $[\alpha]_{\mathrm{D}}{ }^{25}$ $+26.7\left(c 3.05, \mathrm{CH}_{2} \mathrm{Cl}_{2}\right) .{ }^{1} \mathrm{H}$ NMR $\left(\mathrm{CDCl}_{3}\right) \delta 8.49(\mathrm{~m}$, $1 \mathrm{H}), 8.04(\mathrm{~m}, 1 \mathrm{H}), 7.96(\mathrm{~d}, J=8.5 \mathrm{~Hz}, 1 \mathrm{H}), 7.88(\mathrm{~m}$, 2H), $7.58(\mathrm{~m}, 1 \mathrm{H}), 7.55(\mathrm{~m}, 1 \mathrm{H}), 4.02(\mathrm{~m}, 1 \mathrm{H}), 3.96$ $(\mathrm{m}, 1 \mathrm{H}), 3.51(\mathrm{~m}, 1 \mathrm{H}), 3.45(\mathrm{dd}, J=16.0,6.5 \mathrm{~Hz}, 1 \mathrm{H})$, 3.05 (dd, $J=16.0,5.5 \mathrm{~Hz}, 1 \mathrm{H}), 1.86(\mathrm{~m}, 1 \mathrm{H}), 1.78(\mathrm{~m}$, 
1H), 1.62-1.55 (m, 2H), $1.51(\mathrm{~m}, 1 \mathrm{H}), 1.41(\mathrm{~m}, 1 \mathrm{H})$. ${ }^{13} \mathrm{C} \mathrm{NMR}\left(\mathrm{CDCl}_{3}\right) \delta 198.3,135.5,134.5,132.4,130.1$, 129.6, 128.43, 128.36, 127.7, 126.7, 123.9, 74.4, 68.6, 45.4, 32.0, 25.8, 23.4. TLC: $\mathrm{R}_{\mathrm{f}} 0.36$ (hexane/EtOAc $=$ 3:1). IR (neat): 3508, 2935, 2848, 2739, 2667, 2314, 1680, 1636, 1469, 1387, 1355, 1295, 1209, 1087, 863, $821,747,677,450 \mathrm{~cm}^{-1}$. HRMS Calcd for $\mathrm{C}_{17} \mathrm{H}_{19} \mathrm{O}_{2}$ : $[\mathrm{M}+\mathrm{H}]^{+}$, 255.1380. Found: $\mathrm{m} / z$ 255.1388. HPLC (Daicel Chiralpak AD-H, hexane $/ i-\mathrm{PrOH}=98.5 / 1.5$, flow rate $\left.=2.0 \mathrm{~mL} / \mathrm{min}, \lambda=254 \mathrm{~nm}, 40{ }^{\circ} \mathrm{C}\right): t_{\text {minor }}=$ $35.1 \mathrm{~min}, t_{\text {major }}=47.8 \mathrm{~min}$.

\section{1-(4-Methylphenyl)-2-(tetrahydro-2H-pyran-2- yl)ethanone (5e).}

Yield: $76 \%(24.9 \mathrm{mg}), 94 \% e e$, colorless oil. $[\alpha]_{\mathrm{D}}{ }^{25}$ $+14.9\left(\right.$ c $\left.2.49, \mathrm{CH}_{2} \mathrm{Cl}_{2}\right)$. ${ }^{1} \mathrm{H}$ NMR $\left(\mathrm{CDCl}_{3}\right) \delta 7.86(\mathrm{~m}$, 2H), $7.26(\mathrm{~m}, 2 \mathrm{H}), 3.95(\mathrm{~m}, 1 \mathrm{H}), 3.93(\mathrm{~m}, 1 \mathrm{H}), 3.47$ $(\mathrm{m}, 1 \mathrm{H}), 3.23(\mathrm{dd}, J=16.0,6.0 \mathrm{~Hz}, 1 \mathrm{H}), 2.90(\mathrm{dd}, J=$ 16.0, $6.0 \mathrm{~Hz}, 1 \mathrm{H}), 2.40$ (s, 3H), $1.83(\mathrm{~m}, 1 \mathrm{H}), 1.74$ (m, $1 \mathrm{H}), 1.58(\mathrm{~m}, 1 \mathrm{H}), 1.54(\mathrm{~m}, 1 \mathrm{H}), 1.49(\mathrm{~m}, 1 \mathrm{H}), 1.35$ $(\mathrm{m}, 1 \mathrm{H}) .{ }^{13} \mathrm{C}$ NMR $\left(\mathrm{CDCl}_{3}\right) 198.0,143.8,134.7$, 129.2, 128.4, 74.4, 68.6, 45.2, 32.0, 25.8, 23.4, 21.6. TLC: $\mathrm{R}_{\mathrm{f}} 0.44$ (hexane/EtOAc $=3: 1$ ). IR (neat): 2933, 2853, 2360, 2331, 1686, 1607, 1087, 1045, 971, 475, $448 \mathrm{~cm}^{-1}$. HRMS Calcd for $\mathrm{C}_{14} \mathrm{H}_{19} \mathrm{O}_{2}:[\mathrm{M}+\mathrm{H}]^{+}$, 219.1380. Found: $m / z$ 219.1389. HPLC (Daicel Chiralpak AD-H, hexane $/ i-\mathrm{PrOH}=98.5 / 1.5$, flow rate $=0.5 \mathrm{~mL} / \mathrm{min}, \lambda=254 \mathrm{~nm}, 40{ }^{\circ} \mathrm{C}$ ): $t_{\text {minor }}=24.0 \mathrm{~min}$, $t_{\text {major }}=30.7 \mathrm{~min}$.

\section{1-(4-Bromophenyl)-2-(tetrahydro-2H-pyran-2- yl)ethanone (5f).}

Yield: $99 \%(42.1 \mathrm{mg}), 94 \% e e$, white solid. $[\alpha]_{\mathrm{D}}{ }^{25}$ $+10.9\left(c 4.21, \mathrm{CH}_{2} \mathrm{Cl}_{2}\right)$. ${ }^{1} \mathrm{H} \mathrm{NMR}\left(\mathrm{CDCl}_{3}\right) \delta 7.81(\mathrm{~m}$, 2H), $7.56(\mathrm{~m}, 2 \mathrm{H}), 3.92(\mathrm{~m}, 1 \mathrm{H}), 3.90(\mathrm{~m}, 1 \mathrm{H}), 3.41$ $(\mathrm{m}, 1 \mathrm{H}), 3.22(\mathrm{dd}, J=16.0,7.0 \mathrm{~Hz}, 1 \mathrm{H}), 2.83(\mathrm{dd}, J=$ $16.0,5.5 \mathrm{~Hz}, 1 \mathrm{H}), 1.79(\mathrm{~m}, 1 \mathrm{H}), 1.70(\mathrm{~m}, 1 \mathrm{H}), 1.59-$ $1.52(\mathrm{~m}, 2 \mathrm{H}), 1.48(\mathrm{~m}, 1 \mathrm{H}), 1.35(\mathrm{~m}, 1 \mathrm{H}),{ }^{13} \mathrm{C}$ NMR $\left(\mathrm{CDCl}_{3}\right) \delta 197.4,135.8,131.7,129.7,128.2,74.2$, 68.5, 45.2, 31.9, 25.7, 23.3. Mp. 55.3-55.5 ${ }^{\circ} \mathrm{C}$. TLC: $\mathrm{R}_{\mathrm{f}} 0.49$ (hexane/EtOAc $\left.=3: 1\right)$. IR $(\mathrm{KBr}): 2960,2937$, 2924, 2845, 1684, 1584, 1400, 1207, 1087, 1072, 999, 973, 835, $807 \mathrm{~cm}^{-1}$. HRMS Calcd for $\mathrm{C}_{13} \mathrm{H}_{16} \mathrm{BrO}_{2}$ : $[\mathrm{M}+\mathrm{H}]^{+}, 283.0328$. Found: $m / z$ 283.0339. HPLC (Daicel Chiralpak AD-H, hexane $/ i-\mathrm{PrOH}=98 / 2$, flow rate $=2.0 \mathrm{~mL} / \mathrm{min}, \lambda=254 \mathrm{~nm}, 40{ }^{\circ} \mathrm{C}$ ): $t_{\text {minor }}=21.7$ $\min , t_{\text {major }}=25.4 \mathrm{~min}$.

\section{4-Phenyl-1-(tetrahydro-2H-pyran-2-yl)butan-2-one (5g).}

Yield: $58 \%(20.0 \mathrm{mg}), 95 \% e e$, colorless oil. $[\alpha]_{\mathrm{D}}{ }^{25}$ $+3.50\left(\right.$ c 2.00, $\left.\mathrm{CH}_{2} \mathrm{Cl}_{2}\right)$. ${ }^{1} \mathrm{H} \mathrm{NMR}\left(\mathrm{CDCl}_{3}\right) \delta 7.27(\mathrm{~m}$, 2H), 7.20-7.17 (m, 3H), $3.92(\mathrm{~m}, 1 \mathrm{H}), 3.75(\mathrm{~m}, 1 \mathrm{H})$, $3.42(\mathrm{~m}, 1 \mathrm{H}), 2.89(\mathrm{~m}, 2 \mathrm{H}), 2.79(\mathrm{~m}, 2 \mathrm{H}), 2.65(\mathrm{dd}, J$ $=15.5,6.0 \mathrm{~Hz}, 1 \mathrm{H}), 2.38(\mathrm{dd}, J=15.5,4.5 \mathrm{~Hz}, 1 \mathrm{H})$, $1.81(\mathrm{~m}, 1 \mathrm{H}), 1.58(\mathrm{~m}, 1 \mathrm{H}), 1.53-1.46(\mathrm{~m}, 3 \mathrm{H}), 1.25$ $(\mathrm{m}, 1 \mathrm{H}) .{ }^{13} \mathrm{C}$ NMR $\left(\mathrm{CDCl}_{3}\right) \delta 208.5,141.1,130.4$,
128.3, 126.0, 74.1, 68.5, 49.6, 45.2, 31.7, 29.4, 25.7, 23.3. TLC: $\mathrm{R}_{\mathrm{f}} 0.38$ (hexane/EtOAc $=3: 1$ ). IR (neat): 2935, 2854, 1718, 1684, 1653, 1636, 1559, 1539, 1457, 1088, 1044, 747, 699, $456 \mathrm{~cm}^{-1}$. HRMS Calcd for $\mathrm{C}_{15} \mathrm{H}_{21} \mathrm{O}_{2}$ : $[\mathrm{M}+\mathrm{H}]^{+}, \quad 233.1536$. Found: $\mathrm{m} / \mathrm{z}$ 233.1545. HPLC (Daicel Chiralpak AD-H, hexane $/ i$ $\mathrm{PrOH}=98.5 / 1.5$, flow rate $=0.5 \mathrm{~mL} / \mathrm{min}, \lambda=254 \mathrm{~nm}$, $\left.40{ }^{\circ} \mathrm{C}\right): t_{\text {minor }}=14.5 \mathrm{~min}, t_{\text {major }}=15.6 \mathrm{~min}$.

\section{General procedure for asymmetric synthesis of 1,3- dioxolanes 10}

In a 5 -mL vial, we sequentially added $\gamma$-hydroxy- $\alpha, \beta$ unsaturated ketone $\mathbf{8}(0.25 \mathrm{mmol})$, cyclopentyl methyl ether (CPME, $0.5 \mathrm{~mL})$, aldehyde or ketone $9(0.3$ $\mathrm{mmol}$ ), and quinidine-derived bifunctional catalyst 3a $(0.025 \mathrm{mmol})$. The mixture was stirred in an oil bath maintained at $25{ }^{\circ} \mathrm{C}$ for $24 \mathrm{~h}$. The reaction mixture was sequentially diluted with hexane/EtOAc ( $/ \mathrm{v}=$ $1 / 1$ ), passed through a short silica gel pad to remove $\mathbf{3 a}$, and concentrated in vacuo. Purification of the reaction mixture by flash silica gel column chromatography using hexane/EtOAc $(\mathrm{v} / \mathrm{v}=10 / 1)$ as an eluent afforded the corresponding 1,3-dioxolane $\mathbf{3}$ as a mixture of the diastereomers. In most cases, the diastereomers were further separated by flash silica gel column chromatography (see ref 20 for details).

\section{Pocedure for asymmetric oxy-Michael addition reaction to $\gamma$-hydroxy- $\alpha, \beta$-unsaturated thioester 14}

In a 5 -mL vial, we sequentially added $\gamma$-hydroxy- $\alpha, \beta$ unsaturated thioester $14(2.0 \mathrm{mmol})$, cyclopentyl methyl ether (CPME, $2.0 \mathrm{~mL})$, pivalaldehyde (9d, 4.0 $\mathrm{mmol}$ ), and quinidine-derived bifunctional catalyst 3a $(0.26 \mathrm{mmol})$. The mixture was stirred in an oil bath maintained at $25{ }^{\circ} \mathrm{C}$ for $48 \mathrm{~h}$. The reaction mixture was sequentially diluted with hexane/EtOAc (v/v = $1 / 1$ ), passed through a short silica gel pad to remove 3a, and concentrated in vacuo. Purification of the reaction mixture by flash silica gel column chromatography using hexane/ $\mathrm{Et}_{2} \mathrm{O}(\mathrm{v} / \mathrm{v}=10 / 1)$ as an eluent afforded the corresponding oxy-Michael adducts 15 and $\mathbf{1 5}^{\prime}$ as a mixture of the diastereomers.

See ref 14, 20, and 24 for further details on the experimental procedures and the characterization data of compounds.

\section{Acknowledgment}

We thank Professor Takuya Kurahashi (Kyoto University) for $\mathrm{X}$-ray crystallographic analysis. This work was supported financially by the Japanese Ministry of Education, Culture, Sports, Science and Technology.

Supporting Information for this article is available online at http://www.thiemeconnect.com/ejournals/toc/synthesis. 


\section{References}

(1) (a) Fustero, S.; Jiménez, D.; Moscardó, J.; Catalán, S.; del Pozo, C. Org. Lett. 2007, 9, 5283. (b) Fustero, S.; Moscardó, J.; Jiménez, D.; Pérez-Carrión, M. D.; Sánchez-Roselló, M.; del Pozo, C. Chem.-Eur. J. 2008, 14, 9868. (c) Carlson, E. C.; Rathbone, L. K.; Yang, H.; Collett, N. D.; Carter, R. G. J. Org. Chem. 2008, 73, 5155.

(2) (a) Bandini, M.; Bottoni, A.; Eichholzer, A.; Miscione, G. P.; Stenta, M. Chem.-Eur. J. 2010, 16, 12462. (b) Bandini, M.; Eichholzer, A.; Tragni, M.; Umani-Ronchi, A. Angew. Chem. Int. Ed. 2008, 47, 3238.

(3) (a) Uozumi, Y.; Kato, K.; Hayashi, T. J. Am. Chem. Soc. 1997, 119, 5063. (b) Trost, B. M.; Shen, H. C.; Dong, L.; Surivet, J.-P.; Sylvain, C. J. Am. Chem. Soc. 2004, 126, 11966. (c) Zhang, Z.; Widenhoefer, R. A. Angew. Chem. Int. Ed. 2007, 46, 283. (d) Chung, Y. K.; Fu, G. C. Angew. Chem. Int. Ed. 2009, 48, 2225. (e) Wang, L.; Liu, X.; Dong, Z.; Fu, X.; Feng, X. Angew. Chem. Int. Ed. 2008, 47, 8670 .

(4) Intramolecular oxy-Michael addition reaction by proline-derived catalyst was investigated, but the enantioselectivity is modest, see: Díez, D.; Núñez, M. G.; Benéitez, A.; Moro, R. F.; Marcos, I. S.; Basabe, P.; Broughton, H. B.; Urones, J. G. Synlett 2009, 390.

(5) For reviews, see: (a) Hydrogen Bonding in Organic Synthesis; Pihko, P. M., Ed.; Wiley-VCH: Weinheim, 2009. (b) Doyle, A. G.; Jacobsen, E. N. Chem. Rev. 2007, 107, 5713. (c) Taylor, M. S.; Jacobsen, E. N. Angew. Chem. Int. Ed. 2006, 45, 1520.

(6) For selected examples, see: (a) Zhang, W.; Zheng, S.; Liu, N.; Werness, J. B.; Guzei, I. A.; Tang, W. J. Am. Chem. Soc. 2010, 132, 3664. (b) Veitch, G. E.; Jacobsen, E. N. Angew. Chem. Int. Ed. 2010, 49, 7332. (c) Zhou, L.; Tan, C. K.; Jiang, X.; Chen, F.; Yeung, Y.-Y. J. Am. Chem. Soc. 2010, 132, 15474. (d) Tan, C. K.; Zhou, L.; Yeung, Y.-Y. Synlett 2011, 1335.

(7) For examples of organocatalytic asymmetric cycloetherifications via intramolecular oxy-Michael addition, see: (a) Biddle, M. M.; Lin, M.; Scheidt, K. A. J. Am. Chem. Soc. 2007, 129, 3830. (b) Li, D. R.; Murugan, A.; Falck, J. R. J. Am. Chem. Soc. 2008, 130, 46. (c) Gu, Q.; Rong, Z.-Q.; Zheng, C.; You, S.-L. J. Am. Chem. Soc. 2010, 132, 4056. (d) Rubush, D. M.; Morges, M. A.; Rose, B. J.; Thamm, D. H.; Rovis, T. J. Am. Chem. Soc. 2012, 134, 13554. (e) Wu, W.; Li, X.; Huang, H.; Yuan, X.; Lu, J.; Zhu, K.; Ye, J. Angew. Chem. Int. Ed. 2013, 52, 1743. (f) Hintermann, L.; Ackerstaff, J.; Boeck, F. Chem.-Eur. J. 2013, 19, 2311.

(8) In ref $7 \mathrm{~b}$, it is proposed that the tertiary nitrogen atom of the catalyst coordinates to the boron atom of boronic acid hemiester intermediates in the transition state, but we consider that there is the possibility that the tertiary amine may interact with the boronate oxygen through hydrogen bonding.

(9) (a) Čorić, I.; List, B. Nature 2012, 483, 315. (b) Sun, Z.; Winschel, G. A.; Borovika, A.; Nagorny, P. J. Am. Chem. Soc. 2012, 134, 8074.

(10) Hamilton, G. L.; Kang, E. J.; Mba, M.; Toste, F. D. Science 2007, 317, 496.

(11) (a) Chen, G.; Ma, S. Angew. Chem. Int. Ed. 2010, 49, 8306. (b) French, A. N.; Bissmire, S.; Wirth, T. Chem. Soc. Rev. 2004, 33, 354. (c) Kang, S. H.; Kang, S. Y.; Park, C. M.; Kwon, H. Y.; Kim, M. Pure Appl. Chem. 2005, 77, 1269. (d) Kang, S. H.; Lee, S. B.; Park, C. M. J. Am. Chem. Soc. 2003, 125, 15748. (e) Kwon, H. Y.; Park, C. M.; Lee, S. B.; Youn, J.-H.; Kang, S. H. Chem.-Eur. J. 2008, 14, 1023. (f) Kang, S. H.; Park, C.
M.; Lee, S. B.; Kim, M. Synlett 2004, 1279. (g) Hennecke, U.; Müller, C. H.; Fröhlich, R. Org. Lett. 2011, 13, 860. (h) Kang, S. H.; Kim, M.; Kang, S. Y. Angew. Chem. Int. Ed. 2004, 43, 6177. (i) Kang, S. H.; Kim, M. J. Am. Chem. Soc. 2003, 125, 4684. (j) Wilkinson, S. C.; Lozano, O.; Schuler, M.; Pacheco, M. C.; Salmon, R.; Gouverneur, V. Angew. Chem. Int. Ed. 2009, 48, 7083 .

(12) For reviews on oxy-Michael addition reaction, see: (a) Nising, C. F.; Bräse, S. Chem. Soc. Rev. 2008, 37, 1218 (b) Nising, C. F.; Bräse, S. Chem. Soc. Rev. 2012, 41, 988.

(13) (a) Okino, T.; Hoashi, Y.; Takemoto, Y. J. Am. Chem. Soc. 2003, 125, 12672. (b) Okino, T.; Hoashi, Y.; Furukawa, T.; Xu, X.; Takemoto, Y. J. Am. Chem. Soc. 2005, 127, 119. (c) Vakulya, B.; Varga, S.; Csámpai, A.; Soós, T. Org. Lett. 2005, 7, 1967. (d) Hamza, A.; Schubert, G.; Soós, T.; Pápai, I. J. Am. Chem. Soc. 2006, 128, 13151. (e) Connon, S. J. Chem.-Eur. J. 2006, 12, 5418. (f) Zhu, J.-L.; Zhang, Y.; Liu, C.; Zheng, A.-M.; Wang, W. J. Org. Chem. 2012, 77, 9813.

(14) Asano, K.; Matsubara, S. J. Am. Chem. Soc. 2011, 133, 16711.

(15) (a) Merz, H.; Stockhaus, K. J. Med. Chem. 1979, 22 , 1475. (b) Cerè, V.; Mazzini, C.; Paolucci, C.; Pollicino, S.; Fava, A. J. Org. Chem. 1993, 58, 4567. (c) Paolucci, C.; Mazzini, C.; Fava, A. J. Org. Chem. 1995, 60, 169. (d) Laxmi, Y. R. Santosh; Iyengar, D. S. Synthesis 1996, 594.

(16) For our reported procedure for the synthesis of $\gamma$ hydroxy- $\alpha, \beta$-unsaturated carbonyls, see: Sada, M.; Ueno, S.; Asano, K.; Nomura, K.; Matsubara, S. Synlett 2009, 724.

(17) For reviews on the utility of chiral acetals in asymmetric synthesis, see: (a) Alexakis, A.; Mangeney, P. Tetrahedron: Asymmetry 1990, 1, 477. (b) Carreira, E. M.; Kvaerno, L. In Classics in Stereoselective Synthesis; Wiley-VCH: Weinheim, 2009; Chapter 6.

(18) For an example of asymmetric hemiacetal formation/oxy-Michael addition cascade catalyzed by chiral phosphoric acid catalysts, see ref $7 \mathrm{~d}$.

(19) For an example of intramolecular oxy-Michael addition reactions from intermediates generated in situ between $\gamma$-hydroxy- $\alpha, \beta$-unsaturated ketones and boronic acids, see ref $7 b$.

(20) Asano, K.; Matsubara, S. Org. Lett. 2012, 14, 1620.

(21) See ref 20 for details on the X-ray analysis of 10da.

(22) Vanderwal, C. D.; Jacobsen, E. N. J. Am. Chem. Soc. 2004, 126, 14724.

(23) For a review on redox economy in organic synthesis, see: Burns, N. Z.; Baran, P. S.; Hoffmann, R. W. Angew. Chem. Int. Ed. 2009, 48, 2854.

(24) Okamura, T.; Asano, K.; Matsubara, S. Chem. Commun. 2012, 48, 5076.

(25) See ref 24 for details on the stereochemical analysis of $\mathbf{1 5}$ and $\mathbf{1 5}^{\prime}$

(26) For a review on enantioselective formal hydration of $\alpha, \beta$-unsaturated acceptors, see: Hartmann, E.; Vyas, D. J.; Oestreich, M. Chem. Commun. 2011, 47, 7917.

(27) (a) Hollingsworth, R. I.; Wang, G. Chem. Rev. 2000, 100 , 4267. (b) Wang, G.; Hollingsworth, R. I. J. Org. Chem. 1999, 64, 1036. (c) Wang, G.; Hollingsworth, R. I. Tetrahedron: Asymmetry 2000, 11, 4429. (d) Yang, H.; Goyal, N.; Ella-Menye, J. R.; Williams, K.; Wang, G. Synthesis 2012, 561.

(28) (a) Samsung Fine Chemicals Co., Ltd., Process for the Preparation of L-Carnitine, WO/1999/005092, February 4 1999. (b) Kolb, H. C.; Bennani, Y. L.; Sharpless, K. B. Tetrahedron: Asymmetry 1993, 4, 133. 
(29) (a) Liebeskind, L. S.; Srogl, J. J. Am. Chem. Soc. 2000, 122, 11260. (b) Yu, Y.; Liebeskind, L. S. J. Org. Chem. 2004, 69, 3554. 
